\title{
Relationships of shredders, leaf processing and organic matter along a canopy cover gradient in tropical streams
}

\author{
Anna C.F. AGUIAR, ${ }^{1 *}$ Vinicius NERES-LIMA, ${ }^{2}$ Timothy P. MOULTON ${ }^{1,2}$ \\ ${ }^{1}$ Programa de Pós-Graduação em Ecologia, Conservação e Manejo da Vida Silvestre, Universidade Federal de Minas Gerais, Avenida \\ Presidente Antônio Carlos 6627, Belo Horizonte, MG 31270-910; ${ }^{2}$ Departamento de Ecologia, IBRAG, Universidade do Estado do \\ Rio de Janeiro, R. São Francisco Xavier 52, Maracanã, Rio de Janeiro, RJ 20550-013, Brazil \\ *Corresponding author: annacfaguiar@gmail.com
}

\begin{abstract}
Terrestrial allochthonous organic matter represents a structuring element and an important source of energy and carbon to fauna in small forested streams. However, the role of this matter as a food resource for benthic macroinvertebrates, and consequently, for shredders and their performance in riverine processes, is not clear in low-order tropical streams. Aiming to investigate the relationship between shredders and leaves, we analyzed along a gradient of 8-93\% canopy cover biomass and abundance of shredders, accumulated leaves and breakdown rates of local leaves to verify if these parameters were related to shade conditions and to each other. Three hypotheses were tested: i) shredder biomass, accumulated leaves and breakdown rates are related to canopy cover and exhibit higher values in shaded sites; ii) shredder biomass is positively related to accumulated leaves and breakdown rates; and iii) due to the relatively large body size of the important shredders, the association of shredders with leaves and importance to leaf processing should be better expressed in terms of guild biomass than abundance. Shredder biomass varied between 846 and 1506 mg dry mass (DM) $\mathrm{m}^{-2}$ and accumulated leaves varied between 479 and $1120 \mathrm{~g}$ ash free dry mass (AFDM) $\mathrm{m}^{-2}$ across sites. Leaf breakdown rate $(k)$, the only measured variable that varied significantly among sites, varied between -0.0015 and -0.0238 day ${ }^{-1}$. Neither shredder biomass nor leaf biomass were associated with the shading gradient. On the other hand, shredder abundance and biomass, mainly represented by Triplectides (Trichoptera, Leptoceridae), was positively related to accumulated leaves within sites and to breakdown rates assessed by leaf packs. Leaf breakdown, as assessed by the experimental leaf packs, was associated with shredder biomass, but not with shredder abundance. This result suggests that macroinvertebrates are important for leaf detritus processing and that their biomass reflects their activity, presumably because it is related to their secondary production and perhaps non-consumptive action. Their activity was observed at the scale of leaf packs and not at the scale of variation in canopy cover because apparently canopy did not modulate availability of leaves, which were apparently not limiting to the shredders.
\end{abstract}

Key words: Headwater; body size; biomass; benthic macroinvertebrate; leaf breakdown.

Received: June 2017. Accepted: September 2017.

\section{INTRODUCTION}

About $90 \%$ of terrestrial primary production falls directly into the dead organic matter pool (Cebrian, 1999; Abelho, 2001), becoming available to the so-called "brown food webs" (Kaspari, 2004). Especially in loworder streams covered by dense riparian vegetation, allochthonous organic matter represents the main resource for aquatic fauna (Wallace et al., 1997). Leaves compose the major fraction of allochthonous organic matter entering in streams (França et al., 2009; Gonçalves et al., 2014; Bambi et al., 2017) and once in the lotic environment, fauna colonize and start the process of leaf breakdown (Gessner et al., 1999; Graça, 2001; Tank et al., 2010).

Benthic macroinvertebrates have been found to be positively related to the availability of allochthonous organic matter in lotic ecosystems (Egglishaw, 1964; González and Graça, 2005; Mbaka et al., 2015). Leaves and other categories of allochthonous organic matter can provide food and additional resources such as substrate and refuge from predators and water currents (Inoue and Nakano, 1998; Braccia and Batzer, 2001). Also, terrestrial material can accumulate fine particulate organic matter and nutritious biofilms formed by microorganisms which represent food resources for benthic macroinvertebrates (Hax and Golladay, 1993; Crook and Robertson, 1999; Dudgeon and Wu, 1999; Eggert and Wallace, 2007).

Leaves are broken down by physical abrasion, leaching of soluble compounds and through micro and macrofauna consumption (Gessner et al., 1999; Jugnia et al., 2000; Graça, 2001). Macroinvertebrate shredders, organisms that feed directly on leaf tissues while converting coarse matter into small particles, are important in litter breakdown in many systems (Webster and Benfield, 1986; Wallace and Webster, 1996; Graça et al., 2015).

Due to the quantitative dominance of allochthonous matter over autochthonous production in small low-order 
streams, one of the principal tenets of the River Continuum Concept (RCC; Vannote et al., 1980) is that fauna in these parts of the streams rely mainly on terrestrial resources. However, despite the applicability to temperate forested headwaters (Fisher and Likens, 1973; Wallace et al., 1999), RCC is a controversial model in tropical running waters. Evidence from global studies indicates high variability in shredder occurrence and in breakdown rates across tropical sites (Boyero et al., 2012, 2015), which corroborates contrasting results obtained in tropical regions. A growing body of evidence emphasizes the importance of algal carbon in tropical food webs of forested small streams (Salas and Dudgeon, 2001; Mantel et al., 2004; Brito et al., 2006; Li and Dudgeon, 2008; Lau et al., 2009; Neres-Lima et al., 2016; Brett et al., 2017) and it has been claimed that the contribution of macroinvertebrate shredders to leaf breakdown is small in certain tropical running waters due their scarcity (Dudgeon and Wu, 1999; Dobson et al., 2002; Gonçalves et al., 2006b, 2007; Ardón and Pringle, 2008; Alvim et al., 2015). On the other hand, there is contrary evidence of high diversity and abundance of macroinvertebrate shredders, high secondary production and importance on leaf breakdown (Cheshire et al., 2005; Camacho et al., 2009; Yule et al., 2009; Encalada et al., 2010; Masese et al., 2014; Tonin et al., 2014; Andrade et al., 2017; Neres-Lima et al., 2017).

Independently of the source of carbon supporting fauna, we propose that, in part, shredders and their role have been overlooked in the tropics. Methodological factors could underestimate shredder importance in tropical running waters: benthic macroinvertebrates are frequently assigned to functional feeding groups according to classifications proposed for temperate organisms (Camacho et al., 2009). Thus, certain organisms, abundant in tropical running waters and not usually classified as shredders, like Leptophlebiidae, could be involved in leaf processing (Bello and Cabrera, 2001; Andrade et al., 2017). Also, the scarcity of data based on biomass could hinder the investigation of the role of shredders in tropical streams since common tropical shredders, like caddisflies, have large bodies and data based on abundance can underestimate their importance (Tonin et al., 2014).

Therefore, this study examined benthic macroinvertebrate biomass, leaf standing stock and breakdown rates of the most abundant riparian species along a canopy cover gradient. Our objectives were i) analyze patterns in shredder biomass, accumulated leaves and leaf breakdown rates along a canopy cover gradient; ii) investigate the association of macroinvertebrate shredders with leaf standing stock and leaf breakdown; and iii) verify if shredder association with leaves and contribution to leaf breakdown is more evident in terms of number of individuals or biomass. We hypothesized that shredder biomass, accumulated leaves and leaf breakdown rates follow a gradient in canopy cover, and that shredders are positively related to leaf quantity and to leaf breakdown. We also hypothesized that association between shredders and leaves will be clearer in terms of biomass than in terms of abundance.

\section{METHODS}

\section{Study site}

The study was conducted in Córrego da Andorinha and Rio Barra Pequena, small third-order streams located in a well-preserved dense Atlantic rainforest within the State Park of Ilha Grande Island in Rio de Janeiro State, Brazil $\left(23^{\circ} 04^{\prime}\right.$ to $23^{\circ} 14^{\prime} \mathrm{S}$ and $44^{\circ} 05^{\prime}$ to $44^{\circ} 23^{\prime} \mathrm{W}$; Fig. 1 ). Average annual temperature is $23.2^{\circ} \mathrm{C}$ and average annual precipitation, $2071 \mathrm{~mm}$, according to the nearest meteorological station situated in Angra dos Reis municipality (data from December/2015 - November/2016). Total catchment of Córrego da Andorinha is $\sim 1260$ ha and the highest point is $1030 \mathrm{~m}$ above sea level. Rio Barra Pequena has a catchment area of $\sim 566$ ha. Both streams have a steep bed slope for most their courses, discharging into small tidal estuaries without meanders or transition zones. Substrate is generally well embedded, with large boulders and some sandy stretches. The geology is principally Pre-Cambrian granite; the water chemistry is oligotrophic (total- $\mathrm{N}=180 \mu \mathrm{g} \mathrm{L}^{-1}$, total- $\mathrm{P}=10 \mu \mathrm{g} \mathrm{L}^{-1}, \mathrm{pH}=6.6$ ) and did not change along the stream. Conductivity is $27 \mu \mathrm{Scm}^{-1}$ in Córrego da Andorinha and $33 \mu \mathrm{Scm}^{-1}$ in Rio Barra Pequena.

We selected six sites - one in Rio Barra Pequena, BP, four in Córrego da Andorinha - JAR (Jararaca), CHA (Characidium), LAM (Lambari) and CAP (Capivara) and VAL (Valium), a first order tributary of Córrego da Andorinha (Fig. 1 and Tab. 1). Sites were selected following a canopy cover gradient that varied between $8 \%$ and $93 \%$. VAL, BP and JAR showed higher canopy cover mean values $(93,83$ and $73 \%)$ and LAM and CAP, the lower mean values (12\% and $8 \%$ ) and CHA was intermediate $(55 \%)$. Canopy cover was measured using a spherical densitometer Model-C (Forest Densiometers, Bartlesville, OK, USA). Along 10 equally-spaced transect transects distributed in a $10-\mathrm{m}$ reach, we averaged four readings facing north, south, east and west. Discharge was estimated on two occasions during the leaf breakdown experiment (except in JAR). In each site, we conducted a leaf breakdown experiment over 36 days during January and February/2016. At the same six sites, we sampled benthic macroinvertebrates and leaf standing stock in two campaigns during the leaf breakdown experiment.

\section{Shredder biomass and leaf standing stock}

We collected eight samples of benthic organic matter and associated macroinvertebrate where leaves had accumulated naturally ("litter-banks") - most of them were in 
pools of slow-moving water - using a stovepipe corer (314 $\mathrm{cm}^{2}$ ). We inserted the corer into the substrate and manually collected all leaves, debris and coarse material from the corer and placing them in a bucket. We bailed approximately 20L of water from the corer to the bucket to collect suspended organic matter and macroinvertebrates.
The material inside the bucket was elutriated and poured through a sieve $(250 \mu \mathrm{m}$ mesh). The procedure of elutriation was repeated several times using fresh stream water until rinse water was clear. The material was stored in a plastic bag filled with fresh stream water to maintain organisms alive. We washed organic matter samples through
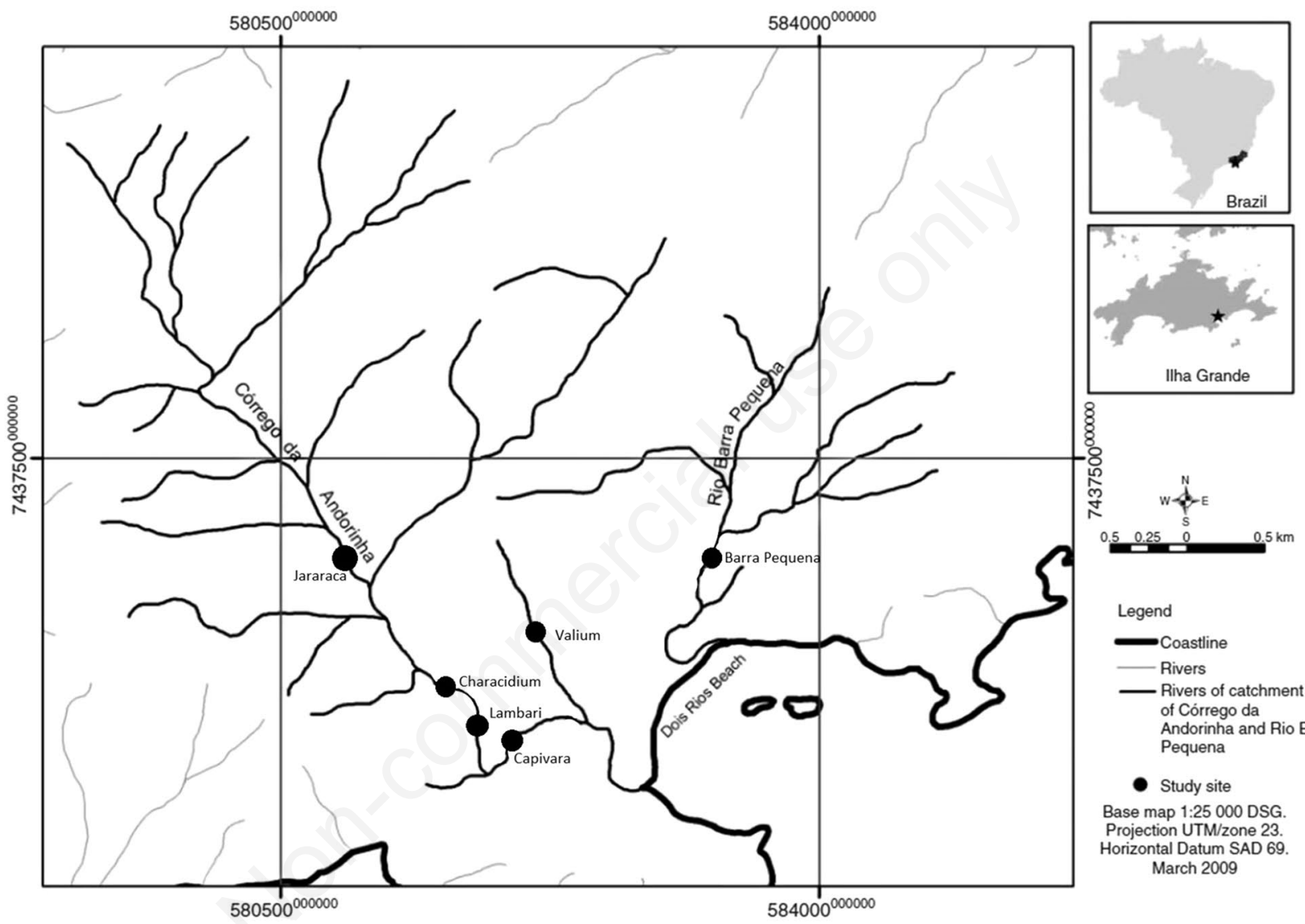

Legend

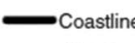

- Rivers

- Rivers of catchment of Córrego da Andorinha and Rio Barra Pequena

- Study site

Base map 1:25 000 DSG. Projection UTM/zone 23 Horizontal Datum SAD 69 March 2009

Fig. 1. Map of the study site at Ilha Grande, Rio de Janeiro.

Tab. 1. Characteristics of the sites.

\begin{tabular}{|c|c|c|c|c|c|c|c|}
\hline \multirow[t]{2}{*}{ Site code } & \multirow[t]{2}{*}{$\begin{array}{c}\text { Site } \\
\text { name }\end{array}$} & \multirow[t]{2}{*}{$\begin{array}{l}\text { Distance from } \\
\text { mouth (m) }\end{array}$} & \multirow[t]{2}{*}{$\begin{array}{l}\text { Altitude } \\
\text { (m asl) }\end{array}$} & \multirow{2}{*}{$\begin{array}{l}\text { Discharge } \\
\left(\mathrm{Ls}^{-1}\right) \\
\text { Mean SD }\end{array}$} & \multirow{2}{*}{$\begin{array}{c}\text { Canopy } \\
\text { cove } r(\%) \\
\text { Mean }\end{array}$} & \multirow{2}{*}{$\begin{array}{l}\text { Leaf input* } \\
\text { (AFDM g m² } \\
\text { month }^{-1} \text { ) } \\
\text { Mean SD }\end{array}$} & \multirow[t]{2}{*}{$\begin{array}{l}\text { Presence of } \\
\text { macro-fauna }\end{array}$} \\
\hline & & & & & & & \\
\hline VAL & Valium & - & 53 & $9.97 \pm 3.19$ & 93 & $129.46 \pm 10.45$ & $\mathrm{M}, \mathrm{P}, \mathrm{T}$ \\
\hline JAR & Jararaca & 2231 & 254 & 91.10 & 73 & $86.19 \pm 31.76$ & $\mathrm{~T}$ \\
\hline BP & Barra Pequena & 236 & 34 & $135.50 \pm 3.53$ & 83 & - & $\mathrm{M}, \mathrm{P}$ \\
\hline CHA & Characidium & 1240 & 83 & $432.80 \pm 42.56$ & 55 & $22.38 \pm 4.64$ & $\mathrm{M}, \mathrm{P}, \mathrm{F}, \mathrm{T}$ \\
\hline LAM & Lambari & 913 & 43 & $531.55 \pm 177.04$ & 12 & $44.78 \pm 0.05$ & M, F \\
\hline CAP & Capivara & 497 & 36 & $565.61 \pm 190.04$ & 8 & $14.15 \pm 1.30$ & $\mathrm{M}, \mathrm{F}$ \\
\hline
\end{tabular}

*Data from January and February/2014 (Lisboa, 2017); F, fishes; M, Macrobrachium (shrimp); P, Potimirim (shrimp); T, Trichodactylus (crab). 
sieves to separate macroinvertebrates and organic matter into coarse $(>1000 \mu \mathrm{m})$ and fine $(>250 \mu \mathrm{m})$ fractions. After removing macroinvertebrates (picked alive and fixed in ethanol $70 \%$ ), leaves were separated for leaf standing stock estimate. The leaves were dried at $55^{\circ} \mathrm{C}$ for $48 \mathrm{~h}$, weighed and then combusted in a muffle furnace at $500^{\circ} \mathrm{C}$ for $4 \mathrm{~h}$ to obtain ash free dry mass (AFDM).

To separate small macroinvertebrates, the fine organic matter fraction was subsampled to a maximum of $1 / 8$ of the sample, depending on the amount of material. We sorted the preserved macroinvertebrates under a stereomicroscope at 40x magnification. All the organisms were identified to the lowest possible taxonomic level with a local key (Mugnai et al., 2009) and classified as shredders or non-shredders according to previous classifications and evidence of food consumption obtained in tropical streams (Cheshire et al., 2005; Rueda-Delgado et al., 2006; Tomanova et al., 2006; Chará-Serna, 2010; Ramírez and Gutiérrez-Fonseca, 2014). Leptophlebiidae was assigned as shredder due to its terrestrial carbon assimilation in Córrego da Andorinha (Neres-Lima et al., 2016) and role in leaf breakdown (Andrade et al., 2017). All organisms were measured (body length) to obtain biomass estimates in mg dry mass $(\mathrm{DM}) \mathrm{m}^{-2}$, using taxon-specific length-mass relationships (Benke et al., 1999). Abundance of each taxon was estimated to number of individuals $\mathrm{m}^{-2}$ and biomass was calculated as a product of abundance and average individual body mass, for each taxon and sample. The estimated biomasses of different taxa were then used to estimate total macroinvertebrate and shredder biomasses.

\section{Leaf breakdown experiment}

At each site, we collected fallen leaves on rocks and boulders following two separate transects of $\sim 5 \mathrm{~m}$ on both margins. Leaves were taken to the laboratory and separated to identify the three most abundant local species in each site (Supplementary Tab. 1). After air-dried and weighed, $\sim 3 \mathrm{~g}$ of leaves were fastened together using paper clips to form bagless packs. Each pack comprised the three most abundant species of each site (Supplementary Tab. 1). Leaf species 1, most abundant, corresponded to $50 \%$ of packs $(\sim 1.5 \mathrm{~g})$ and the same weight of leaf species 2 and $3(\sim 0.7 \mathrm{~g})$ completed the mixed packs. Three groups, here referred to as blocks, of five packs attached to a cord were then incubated in litter-banks placed $\sim 1 \mathrm{~m}$ apart in all sites.

After 2, 6, 11, 27 and 36 days of incubation, three packs, one of each block were randomly retrieved from all sites. The material was stored in plastic bags and taken to the laboratory for analysis of leaf mass loss and biomass of associated shredders. Leaves were gently washed under running water over a $250-\mu \mathrm{m}$ mesh sieve to remove detritus and retain associated benthic fauna (preserved in ethanol $70 \%)$. Leaf material was oven-dried $\left(72 \mathrm{~h}, 55^{\circ} \mathrm{C}\right)$ and ashed $\left(4 \mathrm{~h}, 500^{\circ} \mathrm{C}\right)$ to estimate the remaining AFDM and breakdown rates $(k)$ of leaf packs.

Shredder macroinvertebrates associated with leaf packs were identified and measured for biomass estimates as previously detailed for organisms sampled with stovepipe.

\section{Statistical analyses}

We calculated breakdown rate using the model $\mathrm{M}_{\mathrm{t}}=\mathrm{M}_{0}$ $\mathrm{e}^{-k t}$, where $\mathrm{M}_{\mathrm{t}}$ represents mass (g, AFDM) after time $\mathrm{t}$ (days), $\mathrm{M}_{0}$ represents initial mass and $k$ is the rate of leaf breakdown (per day; Olson, 1973). $\mathrm{M}_{0}$ was calculated as AFDM using DM:AFDM relationship established for each different combination of leaves used in the experiment after combustion of retrieved packs. For each site and cord, $k$ was calculated by linear regression of the natural log of proportion of remaining mass by time (Benfield, 2007). We included the constant of regression and did not include time zero data, which implies excluding the initial time interval (the initial phase of processing can be faster due physical process of leaching, whereas we aimed to measure leaf processing).

Overall variation in leaf standing stock and breakdown rates among sites were analyzed by one-way ANOVA. To analyse differences in shredder abundance and biomass among sites and the association between shredders and leaf standing stock, we performed an ANCOVA using shredder abundance or biomass as dependent variable, leaf AFDM as continuous variable and site as fixed factor. To analyse the relationship between breakdown rates and biomass of shredders associated with experimental leaf packs, we regressed breakdown rates against shredder biomass (means per block). All statistical analyses were conducted using Systat 12.

\section{RESULTS}

\section{Leaves and shredder biomass along a canopy cover gradient}

The standing stock of leaves varied between $479 \pm 422$ and $1120 \pm 960 \mathrm{~g} \mathrm{AFDM} \mathrm{m}^{-2}$ (mean $\pm \mathrm{SD}, \mathrm{n}=8$ ), but quantity of material did not differ significantly among sites

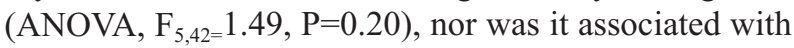
canopy cover (Fig. 2).

Shredder biomass represented $\sim 45 \%$ of total benthic macroinvertebrate biomass in accumulated litter and ranged from $846 \pm 891$ to $1506 \pm 775 \mathrm{mg} \mathrm{DM} \mathrm{m}^{-2}$ in the different sites but showed no apparent relationship with stream size or canopy. Shredder taxa found were the caddisflies Triplectides Kolenati, 1859 (Trichoptera, Leptoceridae), and Phylloicus Mueller, 1880 (Trichoptera, Calamoceratidae), the leaf miner Stenochironomus 
Kieffer 1919 (Diptera, Chironomidae), and leptophlebiids, mainly Farrodes Peter, 1971 (Ephemeroptera). In all sites, except CHA, Triplectides responded for more than half of shredder biomass (Fig. 3).

The abundance and biomass of shredders were positively related to leaf standing stock within sites (Tab. 2 and Fig. 4), but there were no significant differences between sites (Tab. 2).

\section{Leaf breakdown}

Breakdown rates of experimental leaf packs revealed different patterns across sites, but did not exhibit any tendency related to riparian cover (Figs. 5 and 6). In CHA, leaves lost $\sim 30 \%$ of mass by day 11 of the experiment, when, in most other sites, leaf mass loss was less than 20\% (Fig. 5). JAR and BP exhibited slow mass loss, $\sim 25 \%$ until day 36 , and in LAM, leaf mass loss was less than $20 \%$ at the end of experiment (Fig. 5). Breakdown rates showed variation ranging from $-0.0015 \pm 0.0013$ to $-0.0238 \pm 0.0055 \mathrm{~d}^{-1}$ (Fig. 6), with significant difference among sites (ANOVA, $\mathrm{F}_{5,10=} 14.09, \mathrm{P}<0.001$ ). The fastest

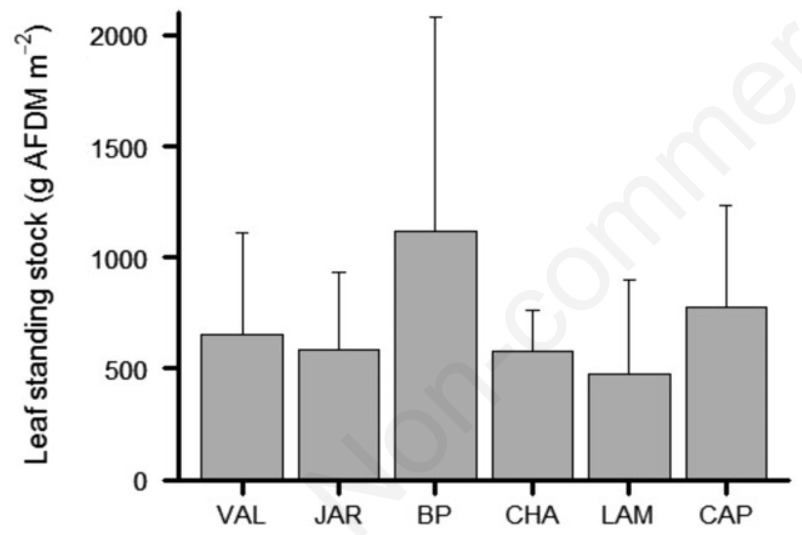

Fig. 2. Leaf standing stock in litter-banks (error bars $=S D, n=8$ ). Sites are ordered in increasing stream size. rate was observed in CHA $\left(k=-0.0238 \pm 0.0055 \mathrm{~d}^{-1}\right)$, significantly different to breakdown rates observed in JAR, BP, LAM and CAP (Fig. 6).

VAL also showed high breakdown rate $(-0.0164 \pm$ $\left.0.0025 \mathrm{~d}^{-1}\right)$, significantly higher than observed in BP and LAM, where we observed the slowest rates (Fig. 6). A total of 534 shredders were found associated with leaves in retrieved packs. The biomass of these organisms exhibited significant relation with leaf breakdown $\left(\mathrm{F}_{1,13=} 13.4\right.$, $\mathrm{P}=0.002$; Fig. 7), but this correlation was more evident in VAL, CHA and CAP. Oppositely, shredder abundance was not significantly related to breakdown rates $\left(\mathrm{F}_{1,16=} 3.34\right.$, $\mathrm{P}=0.086)$.

\section{DISCUSSION}

\section{Longitudinal patterns in shredders and leaves}

Contrary to some studies conducted in tropical ecosystems, we did not detect a pattern of decrease in shredder biomass along a longitudinal gradient (Greathouse and

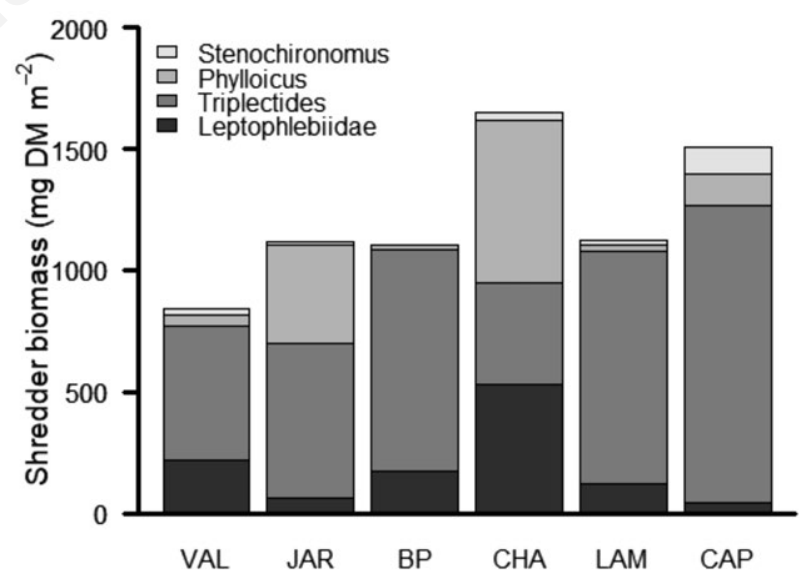

Fig. 3. Biomass of main shredder taxa in studied sites (mean, $\mathrm{n}=8)$.

Tab. 2. Analysis of covariance of shredder abundance and biomass with leaf biomass and sites.

\begin{tabular}{|c|c|c|c|c|c|c|}
\hline Dependent variable & Source of variation & Sum of squares & df & Mean square & $F$-ratio & $\mathbf{P}$ \\
\hline \multirow{4}{*}{ Shredder abundance } & Leaves & 5048 & 1 & 5048 & 4.69 & 0.037 \\
\hline & Sites & 2656 & 5 & 531 & 0.49 & 0.779 \\
\hline & Leaves*sites & 4865 & 5 & 973 & 0.90 & 0.489 \\
\hline & Error & 38,735 & 36 & 1075 & & \\
\hline \multirow{4}{*}{ Shredder biomass } & Leaves & 7692 & 1 & 7692 & 4.39 & 0.043 \\
\hline & Sites & 5206 & 5 & 1041 & 0.59 & 0.705 \\
\hline & Leaves*sites & 13,690 & 5 & 2738 & 1.56 & 0.196 \\
\hline & Error & 63,110 & 36 & 1753 & & \\
\hline
\end{tabular}

df, degrees of freedom. 
Pringle, 2006; Jiang et al., 2011). We also did not observe a positive relationship between canopy cover, accumulated leaves and breakdown, as had been expected. The stock of litter in streams can often reflect the organic matter input from adjacent vegetation (Bilby and Likens, 1980; Swanson et al., 1982), and exhibit similar patterns (Bambi et al., 2017). However, the presence and persistence of terrestrial material in the streambed is also related to several factors including composition, organization and densities of trees, seasonality and channel morphology (Fleituch, 2001; Gonçalves et al., 2006a; França et al., 2009; Tank et al., 2010; Flores et al., 2013; Lisboa et al., 2015; Bambi et al., 2017). Therefore, even with variation among sites in the degree of canopy cover and leaf input (Tab. 1), the lack of substantial differences in leaf standing stock indicates that canopy cover did not determine patterns in organic matter distribution in stream channel. In Córrego da Andorinha and Barra Pequena, channel morphology is possibly a more important factor governing the accumulation of litter.

In an Atlantic Forest environmental quality assessment, Baptista et al. (2007) concluded that shredder abundance was related to reference sites. In general, reference sites exhibit features that match with shredders demands, like litter accumulation and lower temperatures due riparian vegetation presence. Accumulated allochthonous organic matter can provide food for shredders and the positive correlation between these elements is well-established in temperate ecosystems (Richardson, 1992; Wallace et al., 1999; Rowe and Richardson, 2001; González and Graça, 2005; Flores et al., 2013). In this manner, as our studied sites are in the same well-preserved rainforest and accumulated leaves were not restricted to dense riparian covered sites, shredder biomass and abundance seem not restricted as well.

We can also observe that litter was abundant at all sites relative to the biomass of shredders, and was probably not limiting for their growth and population density. Thus, shredders and other macroinvertebrates may be limited by predators, as has been observed in exclosure experiments in these streams (Moulton et al., 2004; Andrade et al., 2017). If this were the case, we could expect that shredders would seek out the most nutritious and easily assimilated leaves, and thus their action would be observed at the level of leaf packs (see below).

\section{Shredders, accumulated leaves and breakdown rates}

We observed that shredder biomass and abundance were related to quantity of leaves of samples within sites (Tab. 2, Fig. 4). We expected this relationship based on the simple assumption that leaves provide substrate and that number of organisms would increase as substrate availability increased. Only if substrate were limited and the pool of potential shredders constant might we expect that shredder abundance would not increase with substrate availability.

On the other hand, shredder biomass per leaf pack was positively associated with leaf processing (Fig. 7). This association was evident in VAL, CHA and CAP, where leaf breakdown rates were higher. Interestingly, shredder abundance per leaf pack did not show a significant relationship with leaf breakdown rate, which implies the importance of measuring biomass as an indicator of shredder activity. Biomass, as a variable directly associated with secondary production, can potentially better illustrate the role of organisms in processes because secondary production integrates, among other factors, resource consumption and growth rate (Benke, 2010; Benke and Huryn, 2010).

Although the macrofauna of crustaceans and fish could potentially affect leaf breakdown, the pattern of leaf breakdown we observed did not correspond to presence or absence of the different macrofauna (cf Tab. 1 and Fig. 6).

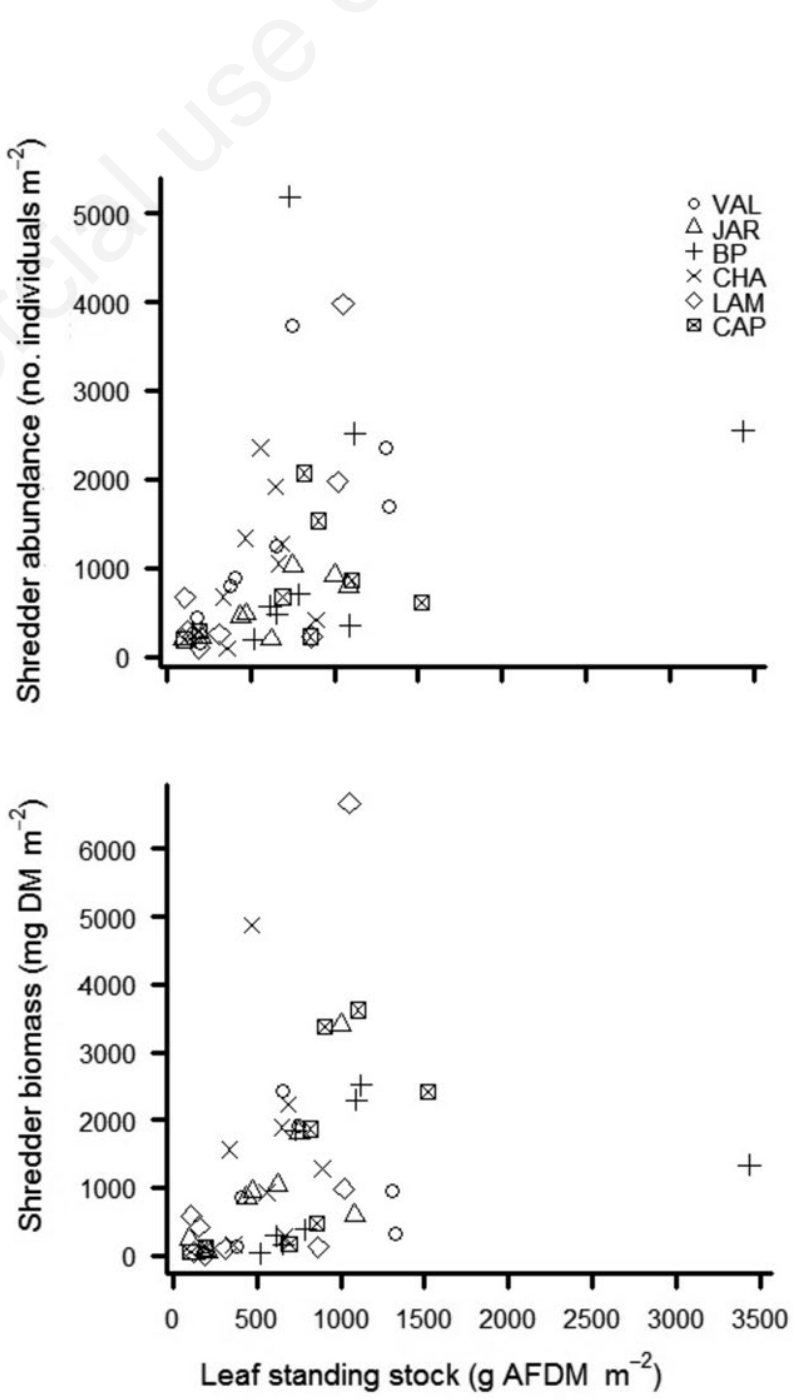

Fig. 4. Relationships among shredder abundance, biomass and leaf standing stock in studied sites. 

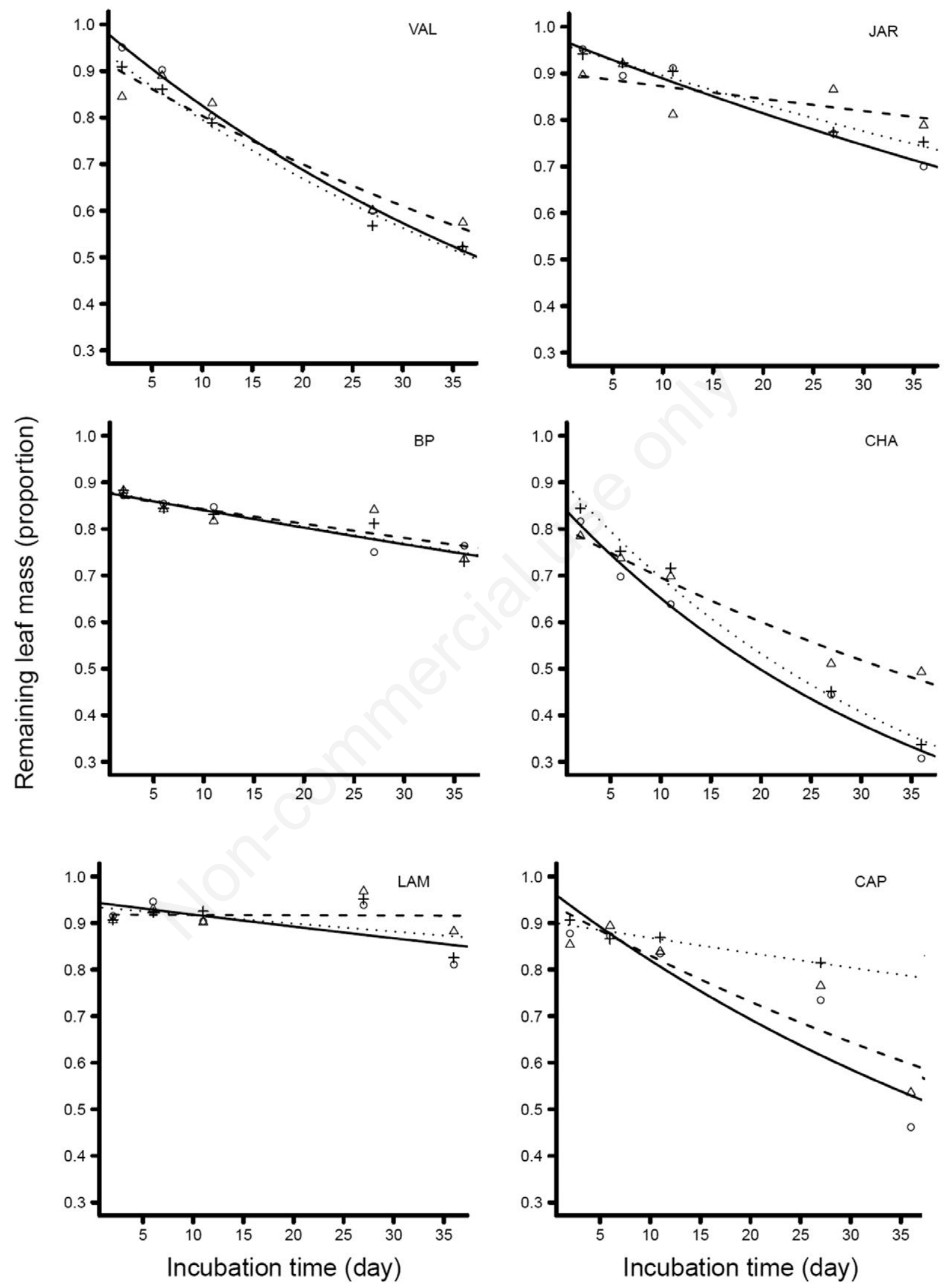

Fig. 5. Proportion of remaining leaf mass for three cords (blocks) over time (days) for leaf packs in all studied sites. Curve fits were to the exponential model. 
Previous research in these streams showed a strong indirect relationship of sites with fish and the density of periphyton (Moulton et al., 2010). Apparently, the presence of fish had an inhibiting effect on grazing shrimp (Potimirim), such that sites with fish had greater density of periphyton. In the current case, however, the sites with fish (LAM and CAP) showed no reduction of leaf processing that could be attributed to an inhibition of shredders. Other possible direct or indirect interactions might have involved Macrobrachium shrimps which were shown to reduce leaf processing presumably by inhibiting shredding insects (Andrade et al., 2017). Again, the site without Macrobrachium, JAR, did not show increased leaf processing.

The leaf packs of the leaf breakdown experiment were made from the three most abundant species of each site. Thus, part of the variation among sites could have come from differences in rates of breakdown of the different species. At site CHA, which showed the fastest breakdown of leaf packs, the most abundant tree species was Ficus insipida Willd. (Moraceae), which exhibited fast breakdown rates in other studies (Rosemond et al., 1998; Ardón et al., 2009; Rincón and Santelloco, 2009). Leaves of $F$. insipida are characterized by low lignin and polyphenol content (Ardón et al., 2006; Rincón and Santelloco, 2009), and are thus a potential high-quality detritus for consumers. In VAL and CHA, where we observed faster leaf breakdown rates, Leptophlebiidae contributed an important fraction of shredder biomass. This observation supports previous local findings that leptophlebiid ephemeropterans are associated with leaf mass loss (Andrade et al., 2017). In JAR and CAP, where breakdown rates can be classified as intermediate and fast, according classifications of Petersen and Cummins (1974) (rapid, $k$ $>0.01 \mathrm{~d}^{-1}$; intermediate, $0.005 \mathrm{~d}^{-1}<k<0.01 \mathrm{~d}^{-1}$; and slow, $k<0.005 \mathrm{~d}^{-1}$ ), we observed association between shredders and accumulated leaves (Fig. 4). In these sites, it was previously observed that Triplectides and Phylloicus diet is not restricted to allochthonous resources, and further, autochthonous resources can correspond to a third (JAR) to a half (CAP) of the food assimilated by these caddisflies in Córrego da Andorinha (Neres-Lima et al., 2016). In JAR, despite high canopy cover, local fauna is highly supported by autochthonous carbon (Neres-Lima et al., 2016). These observations match with the prediction that even highly covered tropical streams have enough light incidence to sustain a reasonable level of primary produc-

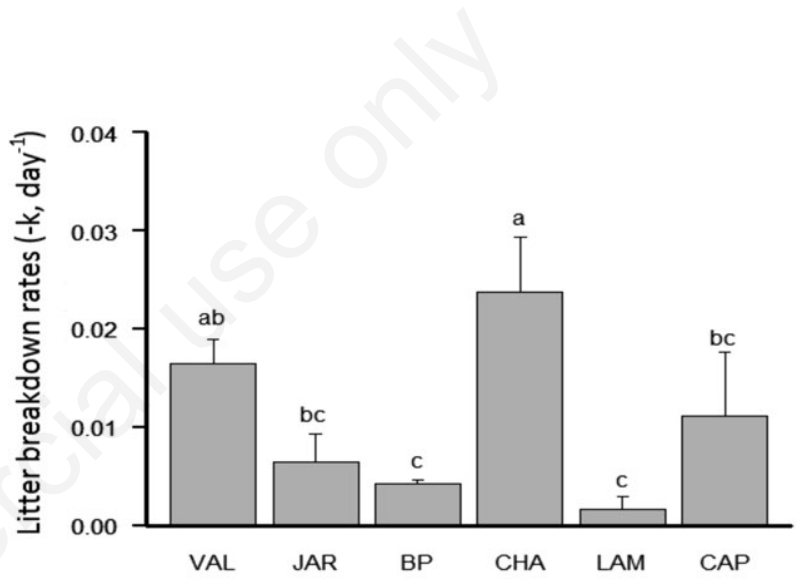

Fig. 6. Breakdown rates $(k)$ of leaf packs in studied sites. Different letters indicate significant differences among sites (Tukey's test, $\mathrm{P}<0.01)$. Error bars are one $\mathrm{SE}$ of the mean $(\mathrm{n}=3)$.

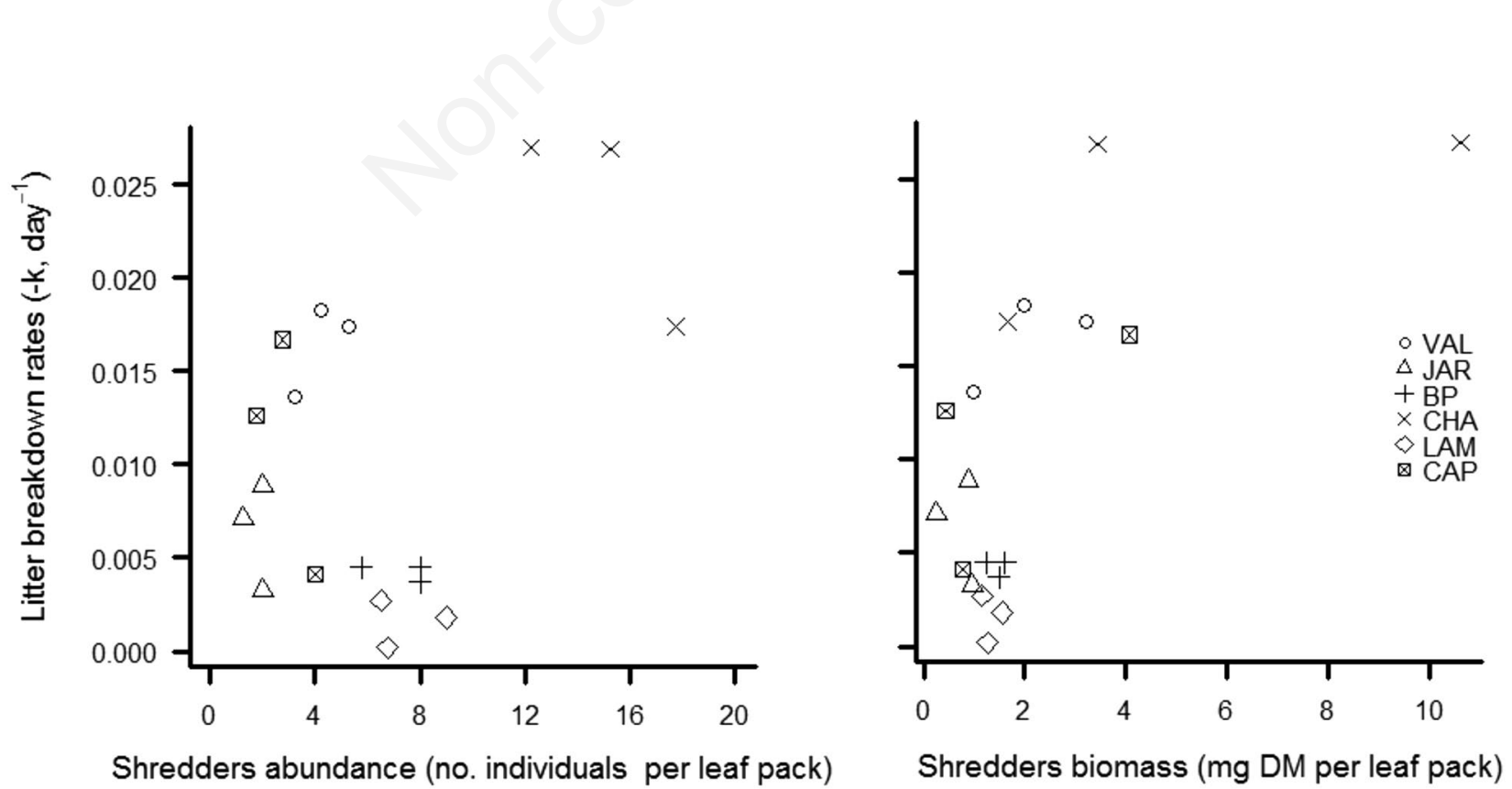

Fig. 7. Relationships between shredder abundance and biomass in leaf packs and litter breakdown rates $(n=3)$. 
tion (Bunn et al., 1999a, 1999b; Lau et al., 2009). In this manner, we speculate that shredders may be consuming some autochthonous carbon along with their predominant diet of leaves and that they might benefit from algae attached to leaves (Guo et al., 2016).

In BP and LAM, where leaf mass loss was almost absent, shredder biomass per leaf pack seems weakly related to breakdown rates (Fig. 7). This observation could indicate that shredders rejected the most abundant local leaves, consuming preferentially other leaves due to their food selection behavior (Casotti et al., 2015). The lack of relationship between shredder biomass and leaf breakdown suggests that shredders were exploiting other food categories. Laboratory experiments indicated that four of five studied species, usually classified as shredders, exhibited generalist behavior, whereas only one species grew up consuming exclusively coarse organic matter (Mihuc and Mihuc, 1995). Additionally, stable isotopes and gut content analyses revealed that organisms classified as shredders can behave as generalists, consuming coarse and fine organic matter and periphyton (Tomanova et al., 2006; Leberfinger and Bohman 2010; Leberfinger et al., 2011; Callisto and Graça, 2013; Ferreira et al., 2015), including in a study conducted in Córrego da Andorinha (Neres-Lima et al., 2016). In this manner, the interaction of shredders and leaves as food resource could be mainly related to litter and algal resources quality than to leaf quantity or canopy cover shading.

\section{CONCLUSIONS}

We conclude that despite the absence of a linkage between canopy cover and shredder abundance and biomass, shredders were associated with leaf quantity within sites and with processing of leaf packs, and thus they appear important for leaf processing. However, this linkage between shredders and accumulated leaves and breakdown was not evident in all sites, which indicates that other factors (e.g. litter and algal resource quality and availability) can be more relevant and determinant in this interaction. Also, shredder biomass rather than abundance was related to leaf breakdown, suggesting that analyses based on biomass may reveal their importance in this ecosystem process. Leptophlebiid ephemeropterans are not generally classified as shredders, but evidence from other studies and their distribution here indicate them as shredders, emphasizing the importance of accurate classifications into functional feeding groups based on regional studies.

\section{ACKNOWLEDGMENTS}

We thank the field and administrative staff of CEADS for their help and immensurable assistance. Professor
André Dias and colleagues from Stream Ecology Laboratory UERJ, Fernanda Motta, Leonardo Lisboa, and Eduardo Silva-Junior for their support infield and discussions. Marcelo Castilhori and Lucas Lopes helped identify the species of leaves. Professor Davi Cunha provided financial support (Science Without Borders/ 88881.068045/2014). Professors Paulina Maia, José Fernandes and Dr. Wander Ferreira gave comments and suggestions. ACF Aguiar and V Neres-Lima received, respectively, $\mathrm{PhD}$ and post-doctoral (88887.091574/201400) scholarships from Coordenação de Aperfeiçoamento de Pessoal de Nível Superior (CAPES). This study forms part of the program of Long-term Integrated Studies: Conservation of the Biodiversity of Ilha Grande, RJ, supported by Fundação de Amparo à Pesquisa do Rio de Janeiro (FAPERJ/Edital 03/2013).

\section{REFERENCES}

Abelho M, 2001. From litterfall to breakdown in streams: a review. Sci. World. J. 1:656-680.

Alvim EACC, Medeiros AO, Rezende RS, Goncalves JF Jr, 2015. Leaf breakdown in a natural open tropical stream. J. Limnol. 74:228-240.

Andrade CM, Neres-Lima V, Moulton TP, 2017. Differentiating the roles of shrimps and aquatic insects in leaf processing in a Neotropical stream. Mar. Freshwater Res. 68:1695-1703.

Ardón M, Pringle CM, 2008. Do secondary compounds inhibit microbial- and insect-mediated leaf breakdown in a tropical rainforest stream, Costa Rica? Oecologia 155:311-323.

Ardón M, Pringle CM, Eggert SL, 2009. Does leaf chemistry differentially affect breakdown in tropical vs temperate streams? Importance of standardized analytical techniques to measure leaf chemistry. J. N. Am. Benthol. Soc. 28:440-453.

Ardón M, Stallcup LA, Pringle CM, 2006. Does leaf quality mediate the stimulation of leaf breakdown by phosphorus in Neotropical streams? Freshwater Biol. 51:618-633.

Bambi P, Rezende RS, Feio MJ, Leite G, Alvin E, Quintão JMB, Araújo F, Gonçalves JF Jr, 2017. Temporal and spatial patterns on inputs and stock of organic matter in savannah streams of central Brazil. Ecosystems 20:757-768.

Baptista DF, Buss DF, Egler M, Giovanelli A, Silveira MP, Nessimian JL, 2007. A multimetric index based on benthic macroinvertebrates for evaluation of Atlantic Forest streams at Rio de Janeiro State, Brazil. Hydrobiologia 575:83-94.

Bello CL, Cabrera MI, 2001. [Alimentación ninfal de Leptophlebiidae (Insecta: Ephemeroptera) en el Caño Paso del Diablo, Venezuela]. [Article in Spanish]. Rev. Biol. Trop. 49:999-1003.

Benfield EF, 2007. Decomposition of leaf material, p. 711-720. In: F.R. Hauer and G.A. Lamberti (eds.), Methods in stream ecology, 2nd edn. New York: Academic Press.

Benke AC, 2010. Secondary production as part of bioenergetic theory - contributions from freshwater benthic science. River Res. Appl. 26:36-44.

Benke AC, Huryn AD, 2010. Benthic invertebrate productionfacilitating answers to ecological riddles in freshwater ecosystems. J. N. Am. Benthol. Soc. 29:264-285. 
Benke AC, Huryn AD, Smock LA, Wallace JB, 1999. Lengthmass relationships for freshwater macroinvertebrates in North America with particular reference to the southeastern United States. J. N. Am. Benthol. Soc. 18:308-343.

Bilby RE, Likens GE, 1980. Importance of organic debris dams in the structure and function of stream ecosystems. Ecology 61:1107-1113.

Boyero L, Pearson RG, Dudgeon D, Ferreira V, Graça MAS, Gessner MO, Boulton AJ, Chauvet E, Yule CM, Albariño RJ, Ramirez A, Helson J, Callisto M, Arunachalam M, Chara J, Figueroa R, Mathooko J, Gonçalves JF Jr, Moretti M, Chara AM, 2012. Global patterns of stream detritivore distribution: implications for biodiversity loss in changing climates. Glob. Ecol. Biogeogr. 21:134-141.

Boyero L, Pearson RG, Gessner MO, Dudgeon D, Ramírez A, Yule CM, Callisto M, Pringle CM, Encalada AC, Arunachalam M, Mathooko J, Helson JE, Rincón J, Bruder A, Cornejo A, Flecker AS, Mathuriau C, M'Erimba C, Gonçalves JF Jr, Moretti MS, Jinggut T, 2015. Leaf-litter breakdown in tropical streams: is variability the norm? Freshw. Sci. 34:759-769.

Braccia A, Batzer DP, 2001. Invertebrates associated with woody debris in a southeastern U.S. forested floodplain wetland. Wetlands 21:18-31.

Brett MT, Bunn SE, Chandra S, Galloway AWE, Guo F, Kainz MJ, Kankaala P, Lau DCP, Moulton TP, Power ME, Rasmussen JB, Taipale SJ, Thorp JH, Wehr JD, 2017. How important are terrestrial organic carbon inputs for secondary production in freshwater ecosystems? Freshwater Biol. 62:833-853.

Brito EF, Moulton TP, Souza ML, Bunn SE, 2006. Stable isotope analysis indicates microalgae as the predominant food source of fauna in a coastal forest stream, south-east Brazil. Austral Ecol. 31:623-633.

Bunn SE, Davies PM, Mosisch TD, 1999a. Ecosystem measures of river health and their response to riparian and catchment degradation. Freshwater Biol. 41:333-45.

Bunn SE, Mosisch TD, Davies PM, 1999b. Temperature and light, p. 17-24. In: S. Lovett and P. Price (eds.), Riparian Land Management Technical Guidelines, Volume One: Principles of Sound Management. Land and Water Resources and Development Corporation, Canberra ACT, Australia.

Callisto M, Graça MAS, 2013. The quality and availability of fine particulate organic matter for collector species in headwater streams. Int. Rev. Hydrobiol. 98:132-140.

Camacho R, Boyero L, Cornejo A, Ibanez A, Pearson RG, 2009. Local variation in shredder distribution can explain their oversight in tropical streams. Biotropica 41:625-632.

Casotti CG, Kiffer Jr WP, Moretti MS, 2015. Leaf traits induce the feeding preference of a shredder of the genus Triplectides Kolenati, 1859 (Trichoptera) in an Atlantic Forest stream, Brazil: a test with native and exotic leaves. Aquat. Insect. 36:43-52.

Cebrian J, 1999. Patterns in the fate of production in plant communities. Am. Nat. 154:449-468.

Chará-Serna AM, Chará JD, Zúñiga MDC, Pedraza GX, Giraldo LP, 2010. [Clasificación trófica de insectos acuáticos en ocho quebradas protegidas de la ecorregión cafetera colombiana], [Article in Spanish] Universitas. Scientiarum $15: 27-36$.

Cheshire K, Boyero L, Pearson RG, 2005. Food webs in tropical
Australian streams: shredders are not scarce. Freshwater Biol. 50:748-769.

Crook DA, Robertson AI, 1999. Relationships between riverine fish and woody debris: implications for lowland rivers. Mar. Fresh. Res. 50:942-953.

Dobson M, Magana A, Mathooko JM, Ndegwa FK, 2002. Detritivores in Kenyan highland streams: more evidence for the paucity of shredders in the tropics? Freshwater Biol. 47:4909-919.

Dudgeon D, Wu KKY, 1999. Leaf litter in a tropical stream: food or substrate for macroinvertebrates? Arch. Hydrobiol. 146:65-82.

Eggert SL, Wallace JB, 2007. Wood biofilm as food resource for stream detritivores. Limnol. Oceanogr. 53:1239-1245.

Egglishaw HJ, 1964. The distributional relationship between the bottom fauna and plant detritus in streams. J. Anim. Ecol. 33:463-476.

Encalada A, Calles J, Ferreira V, Canhoto C, Graça MAS, 2010. Riparian land use and the relationship between the benthos and litter decomposition in tropical montane forest streams. Freshwater Biol. 55:1719-1733.

Ferreira WR, Ligeiro R, Macedo DR, Hughes RM, Kaufmann PR, Oliveira LG, Callisto M, 2015. Is the diet of a typical shredder related to the physical habitat of headwater streams in the Brazilian Cerrado? Ann. Limnol-Int. J. Lim. 51:115-124.

Fisher SG, Likens GE, 1973. Energy flow in Bear Brook, New Hampshire: an integrative approach to stream ecosystem metabolism. Ecol. Monogr. 43:421-439.

Fleituch T, 2001. Beech leaf breakdown and POM storage along an altitudinal stream gradient. Internat. Rev. Hydrobiol. 86:515-525.

Flores L, Díez JR, Larrañaga A, Pascoal C, Elosegui A, 2013. Effects of retention site on breakdown of organic matter in a mountain stream. Freshwater Biol. 58:1267-1278.

França JS, Gregório RS, De D'Arc Paula J, Gonçalves JF Jr, Ferreira FA, Callisto M, 2009. Composition and dynamics of allochthonous organic matter inputs and benthic stock in a Brazilian stream. Mar. Freshw. Res. 60:990-998.

Gessner MO, Chauvet E, Dobson M, 1999. A perspective on leaf litter breakdown in streams. Oikos 85:377-384.

Gonçalves JF Jr, França JS, Callisto M, 2006a. Dynamics of allochthonous organic matter in a tropical Brazilian headstream. Braz. Arch. Biol. Technol. 49:967-973.

Gonçalves JF Jr, França JS, Medeiros AO, Rosa CA, Callisto M, 2006b. Leaf breakdown in a tropical stream. Int. Rev. Hydrobiol. 91:164-177.

Gonçalves JF Jr, Graça MAS, Callisto M, 2007. Litter decomposition in a Cerrado savannah stream is retarded by leaf toughness, low dissolved nutrients and a low density of shredders. Freshwater Biol. 52:1440-1451.

Gonçalves JF Jr, Rezende RS, Gregório RS, Valentin GC, 2014. Relationship between dynamics of litterfall and riparian plant species in a tropical stream. Limnologica 44:40-48.

González JM, Graça MAS, 2005. Influence of detritus on the structure of the invertebrate community in a small Portuguese stream. Internat. Rev. Hydrobiol. 90:534-545.

Graça MAS, 2001. The role of invertebrates on leaf litter decomposition in streams - a review. Int. Rev. Hydrobiol. 86: 383-393.

Graça MAS, Ferreira V, Canhoto C, Encalada AC, Guerrero- 
Bolaño F, Wantzen KM, Boyero L, 2015. A conceptual model of litter breakdown in low order streams. Int. Rev. Hydrobiol. 100: 1-12.

Greathouse EA, Pringle CM, 2006. Does the river continuum concept apply on a tropical island? Longitudinal variation in a Puerto Rican stream. Can. J. Fish. Aquat. Sci. 63:134-152.

Guo F, Kainz MJ, Valdez D, Sheldon F, Bunn SE, 2016. Highquality algae attached to leaf litter boost invertebrate shredder growth. Freshwater Sci. 35:1213-1221.

Hax CL, Gollday SW, 1993. Macroinvertebrate colonization and biofilm development on leaves and wood in a boreal river. Freshwater Biol. 29:79-87.

Inoue M, Nakano S, 1998. Effects of woody debris on the habitat of juvenile masu salmon (Oncorhynchus masou) in northern Japanese streams. Freshwater Biol. 40:1-16.

Jiang X, Xiong J, Xie Z, Chen Y, 2011. Longitudinal patterns of macroinvertebrate functional feeding groups in a Chinese river system: A test for river continuum concept (RCC). Quatern. Int. 244:289-295.

Jugnia LB, Tadonléké RD, Sime-Ngando T, Devaux J, 2000. The microbial food web in the recently flooded sep reservoir: Diel fluctuation in bacterial biomass and metabolic activity in relation to phytoplankton and flagellate grazers. Microb. Ecol. 40:317-329.

Kaspari M, 2004. Using the metabolic theory of ecology to predict global patterns of abundance. Ecology 85:1800-1802.

Lau DCP, Leung KMY, Dudgeon D, 2009. Are autochthonous foods more important than allochthonous resources to benthic consumers in tropical headwater streams? J. N. Am. Benthol. Soc. 28:426-439.

Leberfinger K, Bohman I, 2010. Grass, mosses, algae, or leaves? Food preference among shredders from open-canopy streams. Aquat. Ecol. 44:195-203.

Leberfinger K, Bohman I, Herrmann J, 2011. The importance of terrestrial resource subsidies for shredders in open-canopy streams revealed by stable isotope analysis. Freshwater Biol. 56:470-480.

Li AOY, Dudgeon D, 2008. Food resources of shredders and other benthic macroinvertebrates in relation to shading conditions in tropical Hong Kong streams. Freshwater Biol. 53:2011-2025.

Lisboa LK, 2017. [Carbon budget e spiraling sob a perspectiva teórica de ecossistemas para ecologia de riachos].[PhD thesis in Portuguese]. Universidade do Estado do Rio de Janeiro, Brazil.

Lisboa LK, da Silva ALL, Siegloch AE, Gonçalves JF Jr, Petrucio MM, 2015. Temporal dynamics of allochthonous coarse particulate organic matter in a subtropical Atlantic rainforest Brazilian stream. Mar. Freshw. Res. 66:1-7.

Mantel SK, Salas M, Dudgeon D, 2004. Food web structure in a tropical Asian Forest stream. J. N. Am. Benthol. Soc. 23:728-755.

Masese FO, Kitaka N, Kipkemboi J, Gettel GM, Irvine K, McClain ME, 2014. Macroinvertebrate functional feeding groups in Kenyan highland streams: evidence for a diverse shredder guild. Freshw. Sci. 33:435-450.

Mbaka JG, M'Erimba CM, Mathooko JM, 2015. Impacts of benthic coarse particulate organic matter variations on macroinvertebrate density and diversity in the Njoro river, a Kenyan highland stream. J. East African Nat. Hist. 103:39-48.
Mihuc TB, Mihuc JR, 1995. Trophic ecology of five shredders in a rocky mountain stream. J. Freshwat. Ecol. 10:209-216.

Moulton TP, Souza ML, Silveira RML, Krsulović FAM, 2004. Effects of ephemeropterans and shrimps on periphyton and sediments in a coastal stream (Atlantic forest, Rio de Janeiro, Brazil). J. N. Am. Benthol. Soc. 23:868-881.

Moulton TP, Souza ML, Silveira RML, Krsulović FAM, Silveira MP, Assis JCF, Francischetti CN, 2010. Patterns of periphyton are determined by cascading trophic relationships in two neotropical streams. Mar. Freshw. Res. 61:57-64.

Mugnai R, Nessimian JL, Baptista DF, 2009. [Manual de Identificação de Macroinvertebrados Aquáticos do Estado do Rio de Janeiro].[Book in Portuguese]. Technical Books: 176 pp.

Neres-Lima V, Brito EF, Krsulović FA, Detweiler AM, Hershey AE, Moulton TP, 2016. High importance of autochthonous basal food source for the food web of a Brazilian tropical stream regardless of shading. Int. Rev. Hydrobiol. 101:132-142.

Neres-Lima V, Machado-Silva F, Baptista D, Oliveira RB, Andrade PE, Oliveira AF, Sasada-Sato CY, Silva-Junior EF, Feijó-Lima R, Angelini R, Camargo PB, Moulton TP, 2017. Allochthonous and autochthonous carbon flows in food webs of tropical forest streams. Freshwater Biol. 62: 1012:1023.

Olson JS, 1973. Energy storage and the balance of producers and decomposers in ecological systems. Ecology 44:321-331.

Petersen RC, Cummins KW, 1974. Leaf processing in a woodland stream. Freshwater Biol. 4:343-368.

Ramírez A, Gutiérrez-Fonseca PE, 2014. Functional feeding groups of aquatic insect families in Latin America: a critical analysis and review of existing literature. Rev. Biol. Trop. 62:155-167.

Richardson JS, 1992. Food, microhabitat, or both? Macroinvertebrate use of leaf accumulations in a montane stream. Freshwater Biol. 27:169-176.

Rincón J, Santelloco R, 2009. Aquatic fungi associated with decomposing Ficus sp. leaf litter in a neotropical stream. J. N. Am. Benthol. Soc. 28:416-425.

Rosemond AD, Pringle CM, Ramírez A, 1998. Macroconsumer effects on insect detritivores and detritus processing in a tropical stream. Freshwater Biol. 39:515-523.

Rowe L, Richardson JS, 2001. Community responses to experimental food depletion: resource tracking by stream invertebrates. Oecologia 129:473-480.

Rueda-Delgado G, Wantzen KM, Tolosa MB, 2006. Leaflitter decomposition in an Amazonian floodplain stream: effects of seasonal hydrological changes. J. N. Am. Benthol. Soc. 25:233-249.

Salas M, Dudgeon D, 2001. Stable-isotope determination of mayfly (Insecta: Ephemeroptera) food sources in three tropical Asian streams. Arch. Hydrobiol. 151:17-32.

Swanson FJ, Gregory SV, Sedell JR, Campbell AG, 1982. Landwater interactions: the riparian zone, p. 267-291. In R.L. Edmonds (ed.), Analysis of coniferous forest ecosystems in the Western United States. US/IBP Syn. Ser. 14. Hutchinson Ross Publishing Co., Stroudsburg, PA.

Tank JL, Rosi-Marshall EJ, Griffiths NA, Entrekin SA, Stephen ML, 2010. A review of allochthonous organic matter dynamics and metabolism in streams. J. N. Am. Benthol. Soc. 29: 118-146.

Tomanova S, Goitia E, Helešic J, 2006. Trophic levels and func- 
tional feeding groups of macroinvertebrates in neotropical streams. Hydrobiologia 556:251-264.

Tonin AM, Hepp LU, Restello RM, Gonçalves JF Jr, 2014. Understanding of colonization and breakdown of leaves by invertebrates in a tropical stream is enhanced by using biomass as well as count data. Hydrobiologia 740:79-88.

Vannote RL, Minshall GW, Cummins KW, Sedell JR, Cushing CE, 1980. The river continuum concept. Can. J. Fish. Aquat. Sci. 37:130-137.

Wallace JB, Eggert SL, Meyer JL, Webster JR, 1997. Multiple trophic levels of a forest stream linked to terrestrial litter inputs. Science 277:102-104.
Wallace JB, Eggert SL, Meyer JL, Webster JR, 1999. Effects of resource limitation on a detrital-based ecosystem. Ecol. Monogr. 69:409-442.

Wallace JB, Webster JR, 1996. The role of macroinvertebrates in stream ecosystem function. Annu. Rev. Entomol. 41: 115-139.

Webster JR, Benfield EF, 1986. Vascular plant breakdown in freshwater ecosystems. Annu. Rev. Ecol. Syst. 17:567-594.

Yule CM, Leong MY, Liew KC, Ratnarajah L, Schmidt K, Wong HM, Pearson RG, Boyero L, 2009. Shredders in Malaysia: abundance and richness are higher in cool upland tropical streams. J. N. Am. Benthol. Soc. 28:404-415. 